\title{
Originals
}

\section{Interrelationships of Microangiopathy, Plasma Glucose and Other Risk Factors in 3583 Diabetic Patients: A Multinational Study}

\author{
K. M. West, M. M.S. Ahuja, P. H. Bennett, B. Grab, V. Grabauskas, O. Mateo-de-Acosta, J. H. Fuller, R. J. Jarrett, \\ H. Keen, K. Kosaka, A. S. Krolewski, E. Miki, V.Schliack, and A.Teuscher \\ World Health Organization, Geneva, Oklahoma City, London, Bern, Havana, Warsaw, Berlin (FRG), Tokyo, and Phoenix
}

\begin{abstract}
Summary. In a multinational study, fasting plasma glucose values in 3583 diabetic patients, aged $34-56$ years, were related to the characteristics of these subjects and to the presence and severity of microangiopathy as ascertained by standardised methods. The patients were from nine different populations and ranged in number from 193 to 686 per population (London, Warsaw, Berlin (FRG), New Delhi, Tokyo, Havana, Oklahoma Indians, Arizona Pima Indians, and a national sample in Switzerland). In the total group, mean fasting plasma glucose was $8.1 \mathrm{mmol} / 1$ for those on diet alone, $9.7 \mathrm{mmol} / 1$ for those on oral agents, and $12.7 \mathrm{mmol} / 1$ for insulin-treated patients, of whom $25 \%$ had values exceeding $16.5 \mathrm{mmol} / 1$. Since many variables were measured in each patient, it was possible to take into account many confounding factors in evaluating the relationship of plasma glucose levels to retinopathy and nephropathy.
\end{abstract}

Key words: Diabetes, retinopathy, glomerulosclerosis, microangiopathy, plasma glucose.

A multinational study of the vascular lesions of diabetes has recently been completed under the auspices of the World Health Organization. Reports have been published describing the methods and results [1-4]. The study included 14 populations. Collection of data on plasma glucose was not a required element of the protocol, but in nine populations fasting plasma glucose determinations were performed. The main purpose of this paper is to report the relationship of plasma glucose concentration to retinopathy and nephropathy, and the associations of glucose level and microvascular disease with certain other variables including type of treatment, age, sex, smoking, duration of diabetes, adiposity, age at diagnosis of diabetes and serum cholesterol.

The data are unusual in several respects. The total number of subjects is extraordinarily large (3583). It was possible to compare the interrelationships of many variables in widely disparate circumstances and with few exceptions, standardised procedures were used. Some of the plasma glucose data in one of these nine populations have been reported elsewhere [5].

\section{Subjects and Methods}

The methods used in the WHO study for patient selection and clinical and laboratory measurements have been described previously $[1,4]$. The participants were required to demonstrate the capacity to recruit a representative sample of diabetic patients from a defined population under conditions that would sharply limit the bias that often attends the referral of cases to specialists. The nine populations concerned in this report were drawn from London, Switzerland (nation-wide sample), Warsaw, Berlin (FRG), New Delhi, Tokyo, Havana, Oklahoma (Indians), and Arizona (Pima Indians). In accordance with the WHO protocol, analyses in this report were confined to subjects aged 34 to 56 years. In London, $39 \%$ of the patients who were examined had plasma glucose determinations; in Berlin, 57\%. In each of the seven other centres, more than $90 \%$ had plasma glucose determinations. This paper also reports characteristics of those who did not have plasma glucose determinations and detailed data on those in whom the fasting plasma glucose level was measured. With the exceptions noted below, methods were standardised.

The methods for measuring plasma glucose were not the same in the nine centres. In every case, however, commonly-used 'true glucose' procedures were employed. The methods used were orthotoluidine (Oklahoma and Warsaw), hexokinase (Switzerland), glucose oxidase (Berlin and Havana), Somogyi-Nelson (New Delhi), and ferricyanide (London, Tokyo, and Arizona). Tokyo investigators also used the glucose oxidase method on some of their specimens. Cooper [6] has shown that results are very similar with these particular methods, irrespective of the glucose level. In four populations (Warsaw, New Delhi, Berlin, Tokyo), whole blood specimens were analysed. These latter results were converted to plasma values by adding $15 \%$. Capillary values (Berlin and Tokyo) were re- 
Table 1. Mean fasting plasma glucose levels in each population according to the type of treatment and duration of diabetes (Fasting plasma glucose $(\mathrm{mmol} / \mathrm{l})$

\begin{tabular}{|c|c|c|c|}
\hline Population & Diet only & Oral agent & Insulin \\
\hline \multicolumn{4}{|l|}{ Duration $<7$ years } \\
\hline London & $9.6(12)$ & $10.5(21)$ & $15.7(12)$ \\
\hline Switzerland & $7.6 \quad(32)$ & $9.7 \quad(82)$ & $10.9(17)$ \\
\hline Warsaw & 6.1 (18) & $8.1(81)$ & $13.5(25)$ \\
\hline Berlin, FRG & $6.7(70)$ & $8.9(74)$ & $8.1 \quad$ (3) \\
\hline New Delhi & $6.9(49)$ & $8.6(157)$ & $10.8(21)$ \\
\hline Tokyo & $8.7 \quad(51)$ & $8.6(72)$ & 9.1 (19) \\
\hline Havana & $5.1 \quad(33)$ & $7.6(100)$ & $9.9 \quad(6)$ \\
\hline Oklahoma Indians & $8.9(152)$ & $10.9(247)$ & 10.9 \\
\hline Pima Indians (Arizona) & $11.8(44)$ & $10.6(18)$ & $13.8(10)$ \\
\hline All populations & $8.0(461)$ & $9.3(852)$ & $11.2(186)$ \\
\hline \multicolumn{4}{|l|}{ Duration $7-13$ years } \\
\hline London & $11.7 \quad(3)$ & $11.8 \quad(19)$ & $16.9(29)$ \\
\hline Switzerland & $6.4 \quad(4)$ & $10.8(61)$ & $10.8(76)$ \\
\hline Warsaw & $5.6 \quad(1)$ & $9.5(45)$ & $14.3(81)$ \\
\hline Berlin, FRG & $6.3(58)$ & $9.7(55)$ & 10.9 \\
\hline New Delhi & $12.7 \quad(5)$ & $9.6(134)$ & 13.6 \\
\hline Tokyo & $7.5(30)$ & $8.3(70)$ & $9.1(52)$ \\
\hline Havana & $5.7(23)$ & $8.7(113)$ & $10.7(33)$ \\
\hline Oklahoma Indians & $10.3(29)$ & $12.0(84)$ & $12.4(42)$ \\
\hline Pima Indians (Arizona) & $12.8(27)$ & 11.8 (31) & $14.7(38)$ \\
\hline All populations & $8.3(180)$ & $10.0(612)$ & $12.5(392)$ \\
\hline \multicolumn{4}{|l|}{ Duration $\geqslant 14$ years } \\
\hline London & $6.9 \quad(1)$ & $10.7 \quad(2)$ & $16.9(94)$ \\
\hline Switzerland & $6.5 \quad(2)$ & $10.0(16)$ & $11.4(140)$ \\
\hline Warsaw & $5.9 \quad(1)$ & $10.1(20)$ & $14.4(148)$ \\
\hline Berlin, FRG & $5.6(10)$ & $9.2(19)$ & $12.4(21)$ \\
\hline New Delhi & $8.9 \quad(2)$ & $11.1(57)$ & $11.0(41)$ \\
\hline Tokyo & $7.2 \quad(7)$ & $9.6(29)$ & $9.5(44)$ \\
\hline Havana & $4.2 \quad(5)$ & $10.4(53)$ & $11.8(66)$ \\
\hline Oklahoma Indians & $11.7 \quad(8)$ & $12.8(27)$ & $13.7(44)$ \\
\hline Pima Indians (Arizona) & $10.5 \quad(5)$ & $11.8(10)$ & $14.9(28)$ \\
\hline All populations & $7.7(41)$ & $10.7(233)$ & $13.2(626)$ \\
\hline All durations and all populations $\mathrm{s}^{\mathrm{a}}$ & $8.1 \pm 3.7(682)$ & $9.7 \pm 3.9(1697)$ & $12.7 \pm 5.8(1204)$ \\
\hline
\end{tabular}

Number per cell in parentheses;

$\mathrm{a}=$ mean $\pm \mathrm{SD}$

duced by $6 \%$ to make them equivalent to venous values. This conversion factor was based on the results of several comparative studies summarised by West [7]. Time of collection of the plasma glucose specimens was not standardised among the countries except that all specimens were collected in the morning after an overnight fast. However, because of the very wide range of these glucose values in every population, and in the total sample $(\mathrm{SD}=4.5 \mathrm{mmol} / \mathrm{l})$, this lack of standardisation would produce only a modest effect on the ranking of values in the pooled data. Within countries, standardisation was considerably greater. For this and other reasons, our analyses of the relationships of plasma glucose to microangiopathy include examinations of these relationships within each of the nine populations and for the pooled data.

Urine protein was measured semi-quantitatively by the salicylsulphonic acid method [1]. Those with grade 3 or 4 responses were deemed to have 'heavy' proteinuria. As reported previousiy, cholesterol determinations were performed in a central laboratory on specimens from six of the populations. In Berlin, Warsaw and Havana local values were used. Results obtained locally were not systematically compared with those of our WHO-standardised central laboratory (US Public Health Service, Center for Disease Control, Atlanta). However, mean results from each of the three lo- cal laboratories were found to differ less than $10 \%$ from values obtained by other WHO-standardised laboratories. Even so, this incomplete standardisation should be considered in the interpretation of the serum cholesterol data. Adiposity was computed by relating the body mass index [weight $\left.(\mathrm{kg}) / \mathrm{height}^{2}(\mathrm{~m})\right]$ to a standard for each sex and expressing the results as a percentage of the standard or 'ideal' body mass index (20.6 for females, 22.1 for males) [8]. These standards are the same as those used by the Metropolitan Insurance Company for persons of 'medium frame'.

\section{Results}

\section{Interrelationships of Plasma Glucose and Other Factors}

Table 1 shows the mean fasting plasma glucose values in each of the nine populations and for the pooled data according to the type of treatment and duration of 
Table 2. Relationship of mean fasting plasma glucose levels to adiposity and age at diagnosis of diabetes according to the type of treatment

\begin{tabular}{|c|c|c|c|}
\hline \multirow[t]{2}{*}{ Age at diagnosis } & \multicolumn{3}{|c|}{ Fasting plasma glucose $(\mathrm{mmol} / \mathrm{l})$} \\
\hline & Obese $^{\mathrm{a}}$ & Non-obese & Total $^{b}$ \\
\hline \multicolumn{4}{|c|}{ Insulin-treated patients } \\
\hline$<20$ years & $14.6 \pm 5.2$ & $13.6 \pm 6.8(116)$ & $13.8 \pm 6.5$ \\
\hline $20-34$ years & $14.0 \pm 6.0$ & $12.2 \pm 6.0$ & $12.8 \pm 6.1(608)$ \\
\hline$\geqslant 35$ years & $12.8 \pm 4.9(238)$ & $11.6 \pm 5.2(211)$ & $12.3 \pm 5.1 \quad(451)$ \\
\hline Subtotal & $13.4 \pm 5.4$ & $12.3 \pm 5.9(720)$ & $12.7 \pm 5.8(1204)$ \\
\hline \multicolumn{4}{|c|}{ Patients not receiving insulin } \\
\hline$<20$ years & $9.1 \pm 4.1$ & $10.2 \pm 3.6$ & $9.7 \pm 3.7 \quad$ (19) \\
\hline $20-34$ years & $9.7 \pm 4.2(295)$ & $9.8 \pm 4.3$ & $9.8 \pm 4.2 \quad(519)$ \\
\hline$\geqslant 35$ years & $9.4 \pm 3.9(1217)$ & $8.5 \pm 3.5(620)$ & $9.1 \pm 3.8(1841)$ \\
\hline Subtotal & $9.5 \pm 4.0(1520)$ & $8.9 \pm 3.8 \quad(852)$ & $9.2 \pm 3.9(2379)$ \\
\hline Total & $10.4 \pm 4.7(1999)$ & $10.5 \pm 5.2(1572)$ & $10.4 \pm 4.9(3583)$ \\
\hline
\end{tabular}

a Weight $>114 \%$ of ideal. ${ }^{b}$ In some cells these totals include a few cases where adiposity was not determined

Results expressed as mean \pm SD. Number of cases in parentheses

Table 3. Spearman correlation coefficients of fasting blood glucose and selected variables in each of the nine populations

\begin{tabular}{|c|c|c|c|c|c|c|c|c|}
\hline & $\begin{array}{l}\text { Number } \\
\text { of } \\
\text { patients }\end{array}$ & $\begin{array}{l}\text { Age } \\
\text { (years) }\end{array}$ & & $\begin{array}{l}\text { Age at } \\
\text { diagnosis } \\
\text { (years) }\end{array}$ & Duration & $\begin{array}{l}\% \text { Ideal } \\
\text { body weight }\end{array}$ & $\begin{array}{l}\text { Systolic } \\
\text { blood } \\
\text { pressure }\end{array}$ & $\begin{array}{l}\text { Serum } \\
\text { cholesterol }\end{array}$ \\
\hline London & 193 & -0.11( & $0.14)$ & $-0.31(<0.01)$ & $0.34(<0.01)$ & $0.07(0.36)$ & $-0.01(0.87)$ & $0.11(\quad 0.17)$ \\
\hline Switzerland & 450 & 0.02( & $0.62)$ & $-0.06(\quad 0.22)$ & $0.11(0.02)$ & $0.08(0.08)$ & $0.09(0.07)$ & $0.08(0.09)$ \\
\hline Warsaw & 420 & -0.12( & $0.02)$ & $-0.37(<0.01)$ & $0.39(<0.01)$ & $-0.19(<0.01)$ & $-0.05(0.34)$ & $0.10(0.05)$ \\
\hline Berlin, FRG & 318 & $0.17(<$ & $0.01)$ & $0.01(0.93)$ & $0.18(<0.01)$ & $0.05(\quad 0.38)$ & $0.11(0.05)$ & $0.12(0.03)$ \\
\hline New Delhi & 499 & $-0.01 i$ & $0.82)$ & $-0.21(<0.01)$ & $0.29(<0.01)$ & $-0.04(0.39)$ & $0.04(0.33)$ & $0.05(0.28)$ \\
\hline Tokyo & 374 & -0.11( & $0.04)$ & $0.11(0.03)$ & $0.07(0.15)$ & $0.03(0.62)$ & $0.01(0.77)$ & $0.03(0.55)$ \\
\hline Havana & 432 & 0.09 & 0.07 ) & $-0.16(<0.01)$ & $0.32(<0.01)$ & $-0.24(<0.01)$ & $-0.07(0.14)$ & $0.13(<0.01)$ \\
\hline Oklahoma Indians & 686 & -0.01( & 0.77 ) & $-0.18(<0.01)$ & $0.27(<0.01)$ & $0.06(\quad 0.15)$ & $0.05(0.20)$ & $0.21(<0.01)$ \\
\hline Pima Indians & 211 & $0.02 i$ & $0.78)$ & $-0.13(\quad 0.07)$ & $0.20(<0.01)$ & $0.07(0.28)$ & $0.10(0.16)$ & $0.24(<0.01)$ \\
\hline $\begin{array}{l}\text { Nine populations } \\
\text { combined }\end{array}$ & 3583 & -0.01( & $0.85)$ & $-0.18(<0.01)$ & $0.25(<0.01)$ & $0.02(0.16)$ & $-0.02(0.16)$ & $0.08(<0.01)$ \\
\hline
\end{tabular}

$p$ values in parentheses

In some populations there were small numbers of missing data for certain variables. In no instance was this as great as $10 \%$

diabetes. The mean \pm SD of the plasma glucose values for the pooled data according to the type of treatment are also shown. One of the reasons for interpopulation differences in the mean plasma glucose levels of insulin-treated patients is the interpopulation differences in certain characteristics of this subgroup (e.g. adiposity, age at diagnosis and duration of diabetes). Details of these characteristics have been presented elsewhere $[1,4]$. In every population, mean plasma glucose values of insulin-treated patients were substantially higher than in those not treated with insulin. Insulin-treated patients generally had fasting values that were two to three times higher than normal. Table 2 shows the relationship of glucose level to adipostiy and age at diagnosis of diabetes. In insulintreated patients, mean plasma glucose values were greater in those with an onset of disease early in life. In both insulin-treated patients and in those not re- ceiving insulin, plasma glucose levels were higher in the obese. Although plasma glucose values were highest in obese patients on insulin, inter-individual variation was greatest in lean insulin-treated patients, particularly in young-onset cases.

Only 2\% (20 out of 1204) of the insulin-treated patients had plasma glucose values in the hypoglycaemic range $(<3.3 \mathrm{mmol} / \mathrm{l})$. On the other hand, $25 \%$ had values greater than $16.5 \mathrm{mmol} / 1$.

Table 3 indicates, for each population and for the pooled data, the relationship of several variables to plasma glucose. Some of the relationships found are seen in all populations. The relationship of plasma glucose to the duration of diabetes and to serum cholesterol was consistently positive, while the direction of the relationship of plasma glucose to age and adiposity varied in these populations. In the pooled data, plasma glucose was not strongly correlated with any 
Table 4. Prevalence (\%) of retinopathy and proteinuria according to the type of treatment and duration of diabetes in pooled data of nine populations

\begin{tabular}{|c|c|c|c|c|c|}
\hline \multirow[t]{2}{*}{ Type of treatment } & \multicolumn{5}{|c|}{ Duration of diabetes (years) } \\
\hline & $<7$ & $7-14$ & $14-19$ & $\geqslant 20$ & Total $^{\mathrm{a}}$ \\
\hline \multicolumn{6}{|c|}{ Retinopathy (any grade) } \\
\hline Diet only & $8.9(527)$ & $17.9(196)$ & $25.7 \quad(35)$ & $20.0(10)$ & $12.1(768)$ \\
\hline Oral agent & $15.5(970)$ & $29.6(712)$ & $43.6(188)$ & $41.7 \cdot(73)$ & $24.3(1943)$ \\
\hline Insulin & 18.3 & $42.7 \quad(539)$ & $67.9(489)$ & $74.5(427)$ & $54.3(1706)$ \\
\hline Total & $13.9(1748)$ & $32.9(1447)$ & $59.4(712)$ & $68.6(510)$ & $33.8(4417)$ \\
\hline \multicolumn{6}{|c|}{ Proliferative retinopathy ${ }^{b}$} \\
\hline Diet only & $0.4(527)$ & $2.0(196)$ & $5.7 \quad(35)$ & $0 \quad(10)$ & $1.0(768)$ \\
\hline Oral agent & $0.6(970)$ & $1.7(712)$ & $5.3(188)$ & $5.5(73)$ & $1.6(1943)$ \\
\hline Insulin & $3.2(251)$ & $2.2(539)$ & $5.3(489)$ & $14.3(427)$ & $6.3(1706)$ \\
\hline Total & $0.9(1748)$ & $1.9(1447)$ & $5.3(712)$ & $12.7(510)$ & $3.3(4417)$ \\
\hline \multicolumn{6}{|c|}{ Proteinuria (any degree) } \\
\hline Diet only & $16.9(527)$ & $24.6(195)$ & 26.5 (34) & $10.0(10)$ & $19.2(766)$ \\
\hline Oral agent & $22.2(977)$ & 24.9 (714) & $30.3(188)$ & $28.2(71)$ & $24.2(1950)$ \\
\hline Insulin & $19.0(253)$ & 23.4 & $34.9(495)$ & $33.0(442)$ & $28.5(1728)$ \\
\hline Total & $20.1(1757)$ & $24.3(1447)$ & $33.3(717)$ & $31.9(523)$ & $25.0(4444)$ \\
\hline \multicolumn{6}{|l|}{ Heavy proteinuria } \\
\hline Diet only & $6.5(527)$ & $7.7(195)$ & 11.8 (34) & $10.0(10)$ & $7.1 \quad(766)$ \\
\hline Oral agent & $6.8(977)$ & $8.5(714)$ & $13.3(188)$ & $15.5(71)$ & $8.4(1950)$ \\
\hline Insulin & $5.9(253)$ & 11.2. (538) & $20.8(495)$ & $17.2(442)$ & $14.7(1728)$ \\
\hline Total & $6.5(1757)$ & $9.4(1447)$ & $18.4(717)$ & $16.8(523)$ & $10.6(4444)$ \\
\hline
\end{tabular}

a Includes 895 in whom plasma glucose levels were not measured. ${ }^{b}$ Includes only those in whom proliferation was directly visualised and excludes a small number with prolieferation that was not visable (e.g., because of vitreous opacity). Number of cases in parentheses

of the variables in Table 3, but a statistically significant correlation with plasma glucose was found for blood cholesterol, duration of diabetes and age at diagnosis (the latter inversely).

\section{Plasma Glucose and Microvascular Disease}

Table 4 shows the relationship of the duration of diabetes and type of treatment to the prevalence of retinopathy, proliferative retinopathy, proteinuria, and heavy proteinuria. Microvascular disease was more common in insulin-treated patients. In those not receiving insulin, the prevalence of retinopathy was approximately as great in those with a duration of 14-19 years as in those with a duration of 20 years or more. In insulin-treated patients, however, the prevalence of proliferative lesions was considerably greater in those with a duration of disease of 20 years or more $(14.3 \%)$ than in those with a duration of $14-19$ years $(5.3 \%)$.

Table 5 shows the prevalence of microvascular disease for the pooled data according to the duration of diabetes and level of plasma glucose. The prevalence was higher in those with greater glycaemia. Proteinuria and heavy proteinuria were also more com- mon in those with high plasma glucose levels. This was despite the high frequency of microvascular disease in insulin-treated patients with plasma glucose values in the hypoglycaemic range $(<3.3 \mathrm{mmol} / \mathrm{l})$. In this latter subgroup, $72 \%$ had retinopathy and $42 \%$ proteinuria. When these hypoglycaemic patients were excluded from the analysis, there were even greater differences in the frequency of microvascular disease in the insulin-treated patients with and without severe hyperglycaemia.

Table 6 shows the correlation coefficients of plasma glucose levels with retinopathy and proteinuria. Although highly significant, the strengths of these relationships were quite modest. The correlation of retinopathy with plasma glucose level was significant in every population except Switzerland and Arizona. The direction of this relationship was positive in all nine populations. The correlation coefficient was strongest in Warsaw (0.31) and Berlin (0.30). In London and Switzerland the relationship of proteinuria to the plasma glucose level was not significant, and the association was of borderline significance in Havana $(p=0.07)$ and in Arizona $(p=0.10)$, but the relationship was significant in each of the other populations $(p<0.03)$. 
Table 5. Prevalence of abnormalities according to the duration of diabetes and level of fasting plasma glucose in diabetic patients from pooled data of nine populations

\begin{tabular}{|c|c|c|c|c|c|c|}
\hline \multirow{2}{*}{$\begin{array}{l}\text { Duration } \\
\text { (years) }\end{array}$} & \multirow{2}{*}{$\begin{array}{l}\text { Fasting } \\
\text { plasma } \\
\text { glucose } \\
(\mathrm{mmol} / \mathrm{l})\end{array}$} & \multicolumn{5}{|c|}{ Prevalence of abnormalities $(\%)$} \\
\hline & & Retinopathy & $\begin{array}{l}\text { Severe } \\
\text { retinopathy }\end{array}$ & $\begin{array}{l}\text { Proliferative } \\
\text { retinopathy }\end{array}$ & Proteinuria & $\begin{array}{l}\text { Heavy } \\
\text { proteinuria }\end{array}$ \\
\hline$<7$ & $\begin{array}{l}<11 \\
\geqslant 11\end{array}$ & $\begin{array}{l}10.7(117) \\
17.3(69)\end{array}$ & $\begin{array}{lr}1.0 & (11) \\
2.3 & (9)\end{array}$ & $\begin{array}{ll}0.5 & (5) \\
1.8 & (7)\end{array}$ & $\begin{array}{l}17.9(196) \\
26.4(106)\end{array}$ & $\begin{array}{l}5.5(60) \\
9.7(39)\end{array}$ \\
\hline $7-13$ & $\begin{array}{l}<11 \\
\geqslant 11\end{array}$ & $\begin{array}{l}26.0(181) \\
40.1(191)\end{array}$ & $\begin{array}{ll}3.6 & (25) \\
5.9 & (28)\end{array}$ & $\begin{array}{l}1.7(12) \\
2.7(13)\end{array}$ & $\begin{array}{l}22.4(156) \\
27.1(128)\end{array}$ & $\begin{aligned} 8.5 & (59) \\
12.7 & (60)\end{aligned}$ \\
\hline$\geqslant 14$ & $\begin{array}{l}<11 \\
\geqslant 11\end{array}$ & $\begin{array}{l}55.1(227) \\
66.1(308)\end{array}$ & $\begin{array}{ll}13.8 & (57) \\
15.5 & (72)\end{array}$ & $\begin{array}{l}7.5(31) \\
9.7(45)\end{array}$ & $\begin{array}{l}36.1(150) \\
31.6(149)\end{array}$ & $\begin{array}{ll}20.9 & (87) \\
17.4 & (82)\end{array}$ \\
\hline $14-19$ & $\begin{array}{l}<11 \\
\geqslant 11\end{array}$ & $\begin{array}{l}51.4(129) \\
64.0(176)\end{array}$ & $\begin{array}{l}10.0(25) \\
11.6(32)\end{array}$ & $\begin{array}{l}5.2(13) \\
6.9(19)\end{array}$ & $\begin{array}{l}36.0(91) \\
32.0(88)\end{array}$ & $\begin{array}{ll}20.6 & (52) \\
18.2 & (50)\end{array}$ \\
\hline$\geqslant 20$ & $\begin{array}{l}<11 \\
\geqslant 11\end{array}$ & $\begin{array}{l}60.9(98) \\
69.1(132)\end{array}$ & $\begin{array}{l}19.9(32) \\
20.9(40)\end{array}$ & $\begin{array}{l}11.2(18) \\
13.6(26)\end{array}$ & $\begin{array}{ll}36.2 & (59) \\
31.0 & (61)\end{array}$ & $\begin{array}{ll}21.5 & (35) \\
16.2 & (32)\end{array}$ \\
\hline Total & $\begin{array}{l}<11 \\
\geqslant 11\end{array}$ & $\begin{array}{l}23.9(525) \\
42.4(568)\end{array}$ & $\begin{array}{l}4.2(93) \\
8.1(109)\end{array}$ & $\begin{array}{l}2.2(48) \\
4.8(65)\end{array}$ & $\begin{array}{l}22.8(502) \\
28.4(383)\end{array}$ & $\begin{array}{r}9.3(206) \\
13.4(181)\end{array}$ \\
\hline $\begin{array}{l}\text { Plasma glucose } \\
\text { not measured }\end{array}$ & & $45.5(399)$ & $8.3(73)$ & $3.9(34)$ & $25.5(227)$ & $9.4(84)$ \\
\hline
\end{tabular}

Number of cases in parentheses

We expected that correlations with plasma glucose would be stronger when the degree or grade of microangiopathy (rather than just presence or absence) was used as the dependent variable. This did not prove to be the case. Table 6 shows that the correlations were not appreciably stronger when graded variables were used for retinopathy and proteinuria.

Heavy proteinuria was significantly related to plasma glucose in the pooled data, but this trend did not reach statistical significance when only insulintreated cases were considered. Insulin-treated patients with mild proteinuria had significantly lower plasma glucose levels than insulin-treated patients without proteinuria. Multivariate analyses of the kind described below showed that this inverse relationship was secondary to other confounding factors.

\section{Other Risk Factors and Microvascular Disease}

We have reported previously the associations of lesions of the eye and kidney with risk factors (other than plasma glucose) in these populations [4]. Results of similar analyses are presented in Table 7 . They differ from our previous reports in that data for the sexes are combined, some different analytical methods are used, and results are shown separately for insulintreated cases and for those not treated with insulin. Some associations with retinopathy, such as with duration of diabetes, are so strong that statistically significant relationships were observed in every population, even when the number of subjects was relatively small. Some associations, however, were seen in some
Table 6. Spearman correlation coefficients of plasma glucose with retinopathy and proteinuria in 3583 diabetic patients ${ }^{\mathrm{a}}$

\begin{tabular}{lll}
\hline & $r$ & $p$ \\
\hline Presence of retinopathy $_{\text {Severe retinopathy }}$ & 0.20 & $<0.01$ \\
Grade of retinopathy $^{\mathrm{b}}$ & 0.08 & $<0.01$ \\
Presence of proteinuria $_{\text {Heavy proteinuria }}$ & 0.20 & $<0.01$ \\
Grade of proteinuria $^{\mathrm{c}}$ & 0.08 & $<0.01$ \\
\hline
\end{tabular}

${ }^{a}$ For some indices there were a few missing data, in all cases $<3 \%$. $\quad{ }^{b}$ Severe cases included those with proliferative disease or haemorrhages larger than the optic disc (grade 4). Lesser retinopathy was graded 1-3. ' Four grades $0-3$.

populations, but not in others. A statistically significant association between retinopathy and plasma glucose levels was observed in seven of the nine populations. In all populations, plasma glucose values were higher in those with retinopathy than in those without retinopathy.

The association of blood pressure with retinopathy reached statistical significance in five of the nine populations. Because nephropathy is often associated with hypertension, we examined the relationship of systolic blood pressure and retinopathy in cases without proteinuria. In this subgroup the relationship of retinopathy and blood pressure was not statistically significant. The association of retinopathy with serum cholesterol reached significance in only one of the populations. In every population, retinopathy was significantly associated with the type of treatment 
Table 7. Statistical significance ( $p$ values) of the relationship of the presence of retinopathy and proteinuria with ten variables in nine populations

\begin{tabular}{|c|c|c|c|c|c|c|c|c|c|c|c|}
\hline & \multicolumn{11}{|c|}{ Population } \\
\hline & \multirow{2}{*}{$\begin{array}{l}\text { Switzer- } \\
\text { land }\end{array}$} & \multirow[t]{2}{*}{ Tokyo } & \multirow{2}{*}{$\begin{array}{l}\text { Ari- } \\
\text { zona }\end{array}$} & \multirow[t]{2}{*}{ London } & \multirow[t]{2}{*}{ Warsaw } & \multirow{2}{*}{$\begin{array}{l}\text { Berlin, } \\
\text { FRG }\end{array}$} & \multirow[t]{2}{*}{ Havana } & \multirow{2}{*}{$\begin{array}{l}\text { New } \\
\text { Delhi }\end{array}$} & \multirow{2}{*}{$\begin{array}{l}\text { Okla- } \\
\text { homa }\end{array}$} & \multicolumn{2}{|c|}{ All patients } \\
\hline & & & & & & & & & & $\begin{array}{l}\text { treated } \\
\text { with } \\
\text { insulin }\end{array}$ & $\begin{array}{l}\text { not } \\
\text { taking } \\
\text { insulin }\end{array}$ \\
\hline $\begin{array}{l}\text { Plasma glucose } \\
\text { retinopathy } \\
\text { proteinuria }\end{array}$ & $\begin{array}{l}0.93 \\
0.32\end{array}$ & $\begin{array}{l}0.03 \\
0.04\end{array}$ & $\begin{array}{l}0.75 \\
0.11\end{array}$ & $\begin{array}{l}0.03 \\
0.81\end{array}$ & $\begin{array}{r}<0.01 \\
0.08\end{array}$ & $\begin{array}{r}<0.01 \\
0.01\end{array}$ & $\begin{array}{r}<0.01 \\
0.08\end{array}$ & $\begin{array}{l}<0.01 \\
<0.01\end{array}$ & $\begin{array}{l}<0.01 \\
<0.01\end{array}$ & $\begin{array}{l}0.12 \\
0.02^{\mathrm{c}}\end{array}$ & $\begin{array}{r}<0.01 \\
0.01\end{array}$ \\
\hline $\begin{array}{l}\text { Duration diabetes } \\
\text { retinopathy } \\
\text { proteinuria }\end{array}$ & $\begin{array}{r}<0.01 \\
0.11\end{array}$ & $\begin{array}{l}<0.01 \\
<0.01\end{array}$ & $\begin{array}{l}<0.01 \\
<0.01\end{array}$ & $\begin{array}{r}<0.01 \\
0.24\end{array}$ & $\begin{array}{l}<0.01 \\
<0.01\end{array}$ & $\begin{array}{r}<0.01 \\
0.02\end{array}$ & $\begin{array}{l}<0.01 \\
<0.01\end{array}$ & $\begin{array}{l}<0.01 \\
<0.01\end{array}$ & $\begin{array}{l}<0.01 \\
<0.01\end{array}$ & $\begin{array}{l}<0.01 \\
<0.01\end{array}$ & $\begin{array}{l}<0.01 \\
<0.01\end{array}$ \\
\hline $\begin{array}{l}\text { Serum cholesterol } \\
\text { retinopathy } \\
\text { proteinuria }\end{array}$ & $\begin{array}{l}0.12 \\
0.41\end{array}$ & $\begin{array}{r}0.51 \\
<0.01\end{array}$ & $\begin{array}{l}0.05 \\
0.48\end{array}$ & $\begin{array}{l}0.35 \\
0.97\end{array}$ & $\begin{array}{r}0.08 \\
<0.01\end{array}$ & $\begin{array}{l}0.53 \\
0.23\end{array}$ & $\begin{array}{r}0.14 \\
<0.01\end{array}$ & $\begin{array}{l}0.26 \\
0.10\end{array}$ & $\begin{array}{l}0.40 \\
0.26\end{array}$ & $\begin{array}{r}<0.01 \\
0.01\end{array}$ & $\begin{array}{l}0.35 \\
0.01\end{array}$ \\
\hline $\begin{array}{l}\text { Systolic blood } \\
\text { pressure } \\
\text { retinopathy } \\
\text { proteinuria }\end{array}$ & $\begin{array}{r}0.04 \\
<0.01\end{array}$ & $\begin{array}{r}0.10 \\
<0.01\end{array}$ & $\begin{array}{l}0.02 \\
0.11\end{array}$ & $\begin{array}{r}0.28 \\
<0.01\end{array}$ & $\begin{array}{r}0.08 \\
<0.01\end{array}$ & $\begin{array}{l}0.90 \\
0.01\end{array}$ & $\begin{array}{r}0.01 \\
<0.01\end{array}$ & $\begin{array}{l}<0.01 \\
<0.01\end{array}$ & $\begin{array}{l}<0.01 \\
<0.01\end{array}$ & $\begin{array}{l}<0.01 \\
<0.01\end{array}$ & $\begin{array}{l}<0.01 \\
<0.01\end{array}$ \\
\hline $\begin{array}{l}\text { Smoking } \\
\text { retinopathy } \\
\text { proteinuria }\end{array}$ & $\begin{array}{l}0.42 \\
0.12\end{array}$ & $\begin{array}{l}0.29 \\
0.22\end{array}$ & $\begin{array}{l}-b \\
-b\end{array}$ & $\begin{array}{c}0.49 \\
-b\end{array}$ & $\begin{array}{l}0.85 \\
0.99\end{array}$ & $\begin{array}{l}-b \\
-b\end{array}$ & $\begin{array}{l}0.57 \\
0.83\end{array}$ & $\begin{array}{l}-b \\
-b\end{array}$ & $\begin{array}{l}0.97 \\
0.77\end{array}$ & $\begin{array}{l}0.79 \\
0.46\end{array}$ & $\begin{array}{l}0.24 \\
0.15\end{array}$ \\
\hline $\begin{array}{l}\text { Age } \\
\text { retinopathy } \\
\text { proteinuria }\end{array}$ & $\begin{array}{l}0.36 \\
0.32\end{array}$ & $\begin{array}{l}0.67 \\
0.40\end{array}$ & $\begin{array}{l}0.04 \\
0.40\end{array}$ & $\begin{array}{l}0.94 \\
0.02\end{array}$ & $\begin{array}{l}0.56 \\
0.41\end{array}$ & $\begin{array}{l}0.74 \\
0.12\end{array}$ & $\begin{array}{l}0.04 \\
0.81\end{array}$ & $\begin{array}{r}0.10 \\
<0.01\end{array}$ & $\begin{array}{l}0.02 \\
0.22\end{array}$ & $\begin{array}{l}<0.01 \\
<0.01\end{array}$ & $\begin{array}{l}<0.01 \\
<0.41\end{array}$ \\
\hline $\begin{array}{l}\text { Age at onset of } \\
\text { diabetes } \\
\text { retinopathy } \\
\text { proteinuria }\end{array}$ & $\begin{array}{l}0.01^{\mathrm{c}} \\
0.41\end{array}$ & $\begin{array}{r}<0.01^{\mathrm{c}} \\
0.03^{\mathrm{c}}\end{array}$ & $\begin{array}{l}0.01^{\mathrm{c}} \\
0.12\end{array}$ & $\begin{array}{c}<0.01^{\mathrm{c}} \\
0.95\end{array}$ & $\begin{array}{r}<0.01^{\mathrm{c}} \\
0.01^{\mathrm{c}}\end{array}$ & $\begin{array}{c}<0.01^{\mathrm{c}} \\
0.49\end{array}$ & $\begin{array}{l}0.01^{\mathrm{c}} \\
0.04^{\mathrm{c}}\end{array}$ & $\begin{array}{c}<0.01^{\mathrm{c}} \\
0.12\end{array}$ & $\begin{array}{r}<0.01^{\mathrm{c}} \\
0.01^{\mathrm{c}}\end{array}$ & $\begin{array}{r}<0.01^{\mathrm{c}} \\
0.02^{\mathrm{c}}\end{array}$ & $\begin{array}{r}<0.01^{\mathrm{c}} \\
0.01^{\mathrm{c}}\end{array}$ \\
\hline $\begin{array}{l}\text { Treatment }^{\mathrm{a}} \\
\text { retinopathy } \\
\text { proteinuria }\end{array}$ & $\begin{array}{r}<0.01 \\
0.35\end{array}$ & $\begin{array}{r}<0.01 \\
0.05\end{array}$ & $\begin{array}{l}0.01 \\
0.10\end{array}$ & $\begin{array}{c}<0.01 \\
{ }_{-b}^{b}\end{array}$ & $\begin{array}{r}<0.01 \\
0.01\end{array}$ & $\frac{-{ }^{b}}{0.01}$ & $\begin{array}{r}<0.01 \\
0.03\end{array}$ & $\begin{array}{r}<0.01 \\
0.16\end{array}$ & $\begin{array}{l}0.01 \\
0.21\end{array}$ & $\begin{array}{l}- \\
-\end{array}$ & - \\
\hline $\begin{array}{l}\text { Sex }^{\mathrm{a}} \\
\text { retinopathy } \\
\text { proteinuria }\end{array}$ & $\begin{array}{l}0.97 \\
0.17\end{array}$ & $\begin{array}{l}0.67 \\
0.14\end{array}$ & $\begin{array}{l}0.96 \\
0.30\end{array}$ & $\begin{array}{l}0.87 \\
0.90\end{array}$ & $\begin{array}{l}0.24 \\
0.65\end{array}$ & $\begin{array}{l}0.62 \\
0.22\end{array}$ & $\begin{array}{l}0.34 \\
0.52\end{array}$ & $\begin{array}{c}<0.01^{\mathrm{c}} \\
0.46\end{array}$ & $\begin{array}{l}0.30 \\
0.71\end{array}$ & $\begin{array}{l}0.09 \\
0.25\end{array}$ & $\begin{array}{l}0.08 \\
0.91\end{array}$ \\
\hline $\begin{array}{l}\text { Adiposity } \\
\text { retinopathy } \\
\text { proteinuria }\end{array}$ & $\begin{array}{r}<0.01^{\mathrm{c}} \\
0.05^{\mathrm{c}}\end{array}$ & $\begin{array}{l}0.49 \\
0.28\end{array}$ & $\begin{array}{l}0.02^{\mathrm{c}} \\
0.07\end{array}$ & $\begin{array}{l}0.62 \\
0.45\end{array}$ & $\begin{array}{l}0.02^{\circ} \\
0.57\end{array}$ & $\begin{array}{l}0.02^{c} \\
0.80\end{array}$ & $\begin{array}{c}<0.01^{\mathrm{c}} \\
0.66\end{array}$ & $\begin{array}{c}<0.01^{\mathrm{c}} \\
0.17\end{array}$ & $\begin{array}{c}<0.01^{\mathrm{c}} \\
0.44\end{array}$ & $\begin{array}{l}0.19 \\
0.55\end{array}$ & $\begin{array}{r}<0.01^{\mathrm{c}} \\
0.32\end{array}$ \\
\hline Total no. & 438 & 364 & 193 & 171 & 380 & 303 & 428 & 491 & 682 & 1140 & 2309 \\
\hline
\end{tabular}

Analyses performed by Mann-Whitney $U$ test or by ${ }^{a}$ Chi-square. ${ }^{b}$ Insufficient numbers for accurate p value. ${ }^{c}$ Inverse relationship

(more retinopathy in the insulin-treated) and inversely associated with age at discovery of diabetes. In two of the populations a weak but significant relationship was seen between retinopathy and age. As will be shown below, this association was not significant in the pooled data when duration of diabetes was taken into account (older patients had a longer duration of diabetes).

Retinopathy was not related to cigarette smoking in any of the nine populations. In New Delhi, men had significantly more retinopathy than women, but in all other populations women had a slightly greater frequency of retinopathy than men. This slight excess was not statistically significant in any of the populations. In six of the nine populations, there was a statistically significant inverse association between adiposity and retinopathy.

In general, the associations of these factors with retinopathy were similar in patients treated with insulin and those not treated with insulin. There were, however, some interesting differences. The association of plasma glucose level and retinopathy was not as strong in the insulin-treated cases. In contrast, the relationship of retinopathy to serum cholesterol was 
stronger in the insulin-treated cases. The inverse association of retinopathy with adiposity was weak in the insulin-treated cases.

The same analyses were performed using severe retinopathy as the dependent variable. For this purpose, severe retinopathy was defined as proliferative retinopathy or the presence of one or more haemorrhages larger than the optic disc. The results were very similar to those shown in Table 7. The associations of severe retinopathy with adiposity and age at diagnosis were inverse. The association with serum cholesterol was significant only in insulin-treated cases.

Table 7 also gives the results of univariate analyses of the associations of proteinuria with ten variables. The relationships of proteinuria to adiposity and sex were not significant. A significant relationship with proteinuria to serum cholesterol and plasma glucose levels was observed in both insulin-treated patients and in those who were not taking insulin. The same analyses were performed with heavy proteinuria as the endpoint. The results were very similar to those with proteinuria of any degree, except that overall men had slightly more heavy proteinuria than women. This small difference was statistically significant, but on multivariate analyses, there was no significant difference between the sexes. Statistically significant male predominance of heavy proteinuria was seen in only one of the nine populations (New Delhi).

The duration of diabetes is a major confounding factor in evaluating the association of microangiopathy with other factors of potential aetiological significance. Table 8 shows the relationship of duration to several variables in the pooled data. These associations with duration often have an important influence on the associations of these variables with microangiopathy because of the powerful effect of duration on the presence of microangiopathy.

\section{Multivariate Analysis}

In the multivariate analyses, we did not include blood pressure or cholesterol because both may be increased with nephropathy. Table 9 shows the results of multivariate analysis on the associations of five variables with retinopathy for the pooled data. The factor bearing the strongest association with retinopathy was duration of diabetes, but plasma glucose levels and type of treatment (need for insulin treatment) also had a highly significant relationship to retinopathy. Retinopathy was inversely related to adiposity. Age and sex bore a weak but significant association with retinopathy (slight excess in females).

Multivariate analysis in the group of patients who were not treated with insulin yielded similar results (duration, plasma glucose and leanness were signifi-
Table 8. Correlation coefficients (Pearson method) of duration of diabetes with selected variables

\begin{tabular}{lc}
\hline Variable & $\mathrm{r}$ \\
\hline Sex & $0.01^{\mathrm{a}}$ \\
Age & $0.07^{\mathrm{a}}$ \\
Serum cholesterol & 0.11 \\
Systolic blood pressure & 0.11 \\
Adiposity & -0.24 \\
Plasma glucose & 0.25 \\
Insulin treatment & 0.48 \\
Age at diagnosis of diabetes & $-0.76^{\mathrm{a}}$ \\
\hline
\end{tabular}

a The relationship of duration of diabetes to sex, age and age at diagnosis were influenced by the design of the study [1]

Table 9. Results of multivariate analysis (stepwise logistic regression) relating retinopathy to six variables

\begin{tabular}{lll}
\hline Variable & $p$ & $\begin{array}{l}\text { Maximum } \\
\text { log } \\
\text { likelihood } \\
-2117^{\mathrm{a}}\end{array}$ \\
\hline Duration of diabetes & $<0.001$ & -1823 \\
Insulin treatment & $<0.001$ & -1781 \\
Plasma glucose & $<0.001$ & -1772 \\
Adiposity & $<0.001^{\mathrm{b}}$ & -1765 \\
Age & 0.021 & -1762 \\
Sex & $0.036^{\mathrm{c}}$ & -1759 \\
\hline
\end{tabular}

a Maximum log likelihood before addition of independent variables. The degree of decline, as factors are added, reflects the effect of the variable added. ${ }^{b}$ Inverse relationship, less retinopathy in obese subjects. ${ }^{c}$ Slight excess in females.

Chi-square for goodness of fit was $6(p=0.20)$

Table 10. Results of multivariate analysis (stepwise logistic regression) relating proteinuria to four variables

\begin{tabular}{lll}
\hline Variable & $p$ & $\begin{array}{l}\text { Maximum } \\
\text { log } \\
\text { likelihood } \\
-1934^{\mathrm{a}}\end{array}$ \\
\hline Duration of diabetes & 0.001 & -1907 \\
Age & 0.058 & -1905 \\
Glucose & $0.064^{\mathrm{b}}$ & -1903 \\
Type of treatment & 0.831 & -1903 \\
\hline
\end{tabular}

a Maximum log likelihood before addition of independent variables. The degree of decline in this value, compared with the value above it, reflect the effect of the variable. ${ }^{b}$ Effect of glucose was of borderline statistical significance, but was highly significant $(p<0.001)$ in patients who did not take insulin.

Chi-square for goodness of fit was $5.30(p=0.26)$

cant), but in this subgroup the effects of age and sex did not reach statistical significance. In insulin-treated patients, the relationship of plasma glucose and leanness to retinopathy was not statistically significant but, as in the total group, the direction of the relationship of leanness and plasma glucose levels to retinopathy was positive. 
Results of multivariate analysis for proteinuria are shown in Table 10. Duration had a strong effect. The presence of proteinuria was related with plasma glucose levels and age, although these associations were not strong. The effect of age may be due to the higher frequency of proteinuria in older subjects from causes other than diabetes. In the multivariate analysis, there was no significant association with type of treatment, but when the same analysis was performed for heavy proteinuria instead of proteinuria, a significant relationship was observed between the type of treatment and the more severe lesion (heavy proteinuria was more common in patients treated with insulin). When multivariate analysis was performed on the subgroup of insulin-treated patients, the association between plasma glucose and proteinuria did not reach statistical significance. In those who were not insulin-treated the contribution of glucose level was significant $(p$ $<0.001$ ).

\section{Discussion}

One of the most important and controversial issues in diabetes is the extent to which the degree of hyperglycaemia affects the risk of vascular disease. Results and opinions have differed widely for many reasons. One is that conclusions have often been drawn without taking into account the sometimes powerful effects of confounding variables when rates of microangiopathy are compared among those with varying degrees of hyperglycaemia. Positive associations of any variable with duration of diabetes may suggest, spuriously, that this factor has an aetiological relationship with microangiopathy; or an inverse relationship of such a factor with duration may obscure a causal association with microangiopathy. Our analyses indicated that the relationship of duration to other risk factors was not constant nor easily predictable, varying with the characteristics of the subjects included in the analyses. Among the advantages of this study was the opportunity to take into account many variables in analysing these interrelationships, the large number of subjects, and the opportunity to examine associations in each of nine different populations.

A disadvantage of this study was its cross-sectional nature. Particularly limiting was the fact that a plasma glucose value at any one time is a very crude indicator of previous plasma glucose values. This imprecision would tend to obscure the relationship of plasma glucose and microangiopathy if there were such a relationship. Thus, the association between plasma glucose level and microangiopathy may be considerably stronger than is evident from our study. Certain other aspects of our results support the possibility that plasma glucose level is an important risk factor. There was a highly significant relationship of microvascular disease to leanness and with the type of treatment (higher rates of microangiopathy in insulin-treated patients). It seems very likely that these associations are attributable to the association of these factors with higher plasma glucose levels, both at the time of our examination and in the past. Therapy may be intensified when serious microangiopathy is discovered. This would tend to obscure the relationship between blood glucose level and the risk of microangiopathy in a cross-sectional study of this type. In addition, renal failure may be attended by an amelioration of hyperglycaemia and proteinuria may be caused by diseases other than diabetes. This would tend to hide a relationship of the degree of glycaemia with diabetic nephropathy. Duration of undiscovered diabetes is probably less in insulin-treated patients than in those not treated with insulin. This would also cause an under-estimation of the effect of plasma glucose level when cases were matched for duration of known diabetes. It is, therefore, not surprising that the degree of association of microangiopathy with a single plasma glucose was modest in these circumstances.

Because nephropathy is frequently associated with raised blood pressure, it is difficult to determine in a prevalence study whether blood pressure is a cause of retinopathy or nephropathy. Our data provide no conclusive support for blood pressure as a risk factor for retinopathy or nephropathy, but they do not exclude the possibility that blood pressure is mildly deleterious in this respect.

Some differences were observed among the nine populations in the associations of plasma glucose values with the various factors. However, the general trends were similar. In each of four races (Indians, American Indians, Caucasoids and Japanese), there was a positive relationship between plasma glucose and microvascular disease.

There were interpopulation differences of moderate degree in rates of retinopathy and proteinuria [2, 4]. These differences are partly explained by interpopulation differences in the duration and type of diabetes. Some of the differences were probably attributable to incomplete standardisation of the execution of the standardised protocols for examining the retinae and urine $[1,4]$. In the pooled data, sub-optimal standardisation would cause an under-estimation of the degree of association between variables that were related. Presumably, however, the standardisation would be better within populations. Therefore, we examined these relationships both within and among populations. We are also aware of other grounds for caution in interpreting the results of analyses on pooled data. 
On the other hand, the validity of trends observed in the pooled data were strengthened by confirmation of such trends when the intrapopulation data were examined.

Acknowledgments. Very important contributions of many other participants have been acknowledged in previous publications [1, 4]. Additional collaborators in the glucose-related studies included Drs. J. Stober and L. Erdreich, formerly of the Department of Biostatistics and Epidemiology, College of Health, University of Oklahoma Health Sciences Center, USA. These studies were supported by the World Health Organization, the National Institutes of Health, the Kroc Foundation, and numerous other local groups at the nine sites of this study. This study was a sub-study of the Multinational Study of Vascular Disease in Diabetes, sponsored by the World Health Organization.

K. M.West, M. D., deceased 29 July 1980, was a George Lynn Cross Research Professor, Department of Biostatistics and Epidemiology, University of Oklahoma Health Sciences Center, Oklahoma City, Oklahoma, USA. The final revision of the manuscript was compiled by Dr. J.Stober, Environmental Protection Agency, Health Effects Research Laboratory, Cincinnati, Ohio, USA.

\section{References}

1. Jarrett RJ, Keen H, Grabauskas AV (1979) The WHO multinational study of vascular disease in diabetes: 1. General description. Diabetes Care 2: 175-186
2. Keen H, Jarrett R.J (1979) The WHO multinational study of vascular disease in diabetes: 2. Macrovascular disease. Diabetes Care 2: 187-195

3. Jarrett RJ, Keen H (1979) The WHO multinational study of vascular disease in diabetes: 3. Microvascular disease. Diabetes Care 2: 196-201

4. Jarrett RJ, Keen H, Grabauskas V, West KM and 20 other collaborators (1980) World Health Organization Multinational Study of Vascular Disease in Diabetes. World Health Organization, Geneva

5. West KM, Erdreich LJ, Stober JA (1980) Risk factors for retinopathy and nephropathy in diabetes: a detailed study. Diabetes 29: 501-508

6. Cooper GR (1973) Methods for determining the amount of glucose in blood. CRC Crit Rev Clin Lab Sci 4: 101-145

7. West KM (1978) Measurement of blood glucose. In: Epidemiology of diabetes and its vascular lesions, Elsevier North-Holland, New York, pp 67-68

8. West KM (1980) Computing and expressing degree of fatness. JAMA 243: 1421-1422

Received: 7 May 1981

and in revised form: 22 January 1982

Judy A. Stober, Ph.D.

Environmental Protection Agency

Health Effects Research Laboratory

26 West St. Clair Street

Cincinnati, $\mathrm{OH} 45268$

USA 